\title{
METODE DAN PENDEKATAN DALAM KAJIAN ISLAM
}

\author{
Suparlan \\ STIT Palapa Nusantara Lombok NTB \\ parlan75@yahoo.com
}

\begin{abstract}
Islamic studies is one of the studies that has received attention among scientists. If explored in depth, it appears that Islamic studies began to be widely studied by those interested in religious studies and other studies. Thus, Islamic studies deserve to be used as one of the favorite branches of science. That is, the study of Islam has gained a place in the world of science. Approach is a perspective or paradigm used by a reviewer in analyzing an object of Islamic religion by using certain sciences or theories. Certain sciences or theories are basically used as a tool or analysis tool for problems related to religion so that the object and the environment of study are clearly visible.
\end{abstract}

Keywords: Approach, Islamic Studies

\begin{abstract}
Abstrak : Studi Islam adalah salah satu studi yang mendapat perhatian di kalangan ilmuwan. Jika ditelusuri secara mendalam, nampak bahwa studi Islam mulai banyak dikaji oleh para peminat studi agama dan studi-studi laninya. Dengan demikian, studi Islam layak untuk dijadikan sebagai salah satu cabang ilmu favorit. Artinya, studi Islam telah mendapat tempat dalam percaturan dunia ilmu pengetahuan. Pendekatan adalah cara pandang atau paradigma yang digunakan oleh seorang pengkaji dalam menganalisis suatu objek agama Islam dengan menggunakan ilmu-ilmu atau teoriteori tertentu. Ilmu-ilmu atau teori tertentu itu pada dasarnya digunakan sebagai alat bantu atau alat analisis atas permasalahan yang berkaitan dengan agama sehingga tampak jelas objek dan lingkungan kajiannya.
\end{abstract}

Kata Kunci: Pendekatan, Kajian Islam

\section{PENDAHULUAN}

Studi Islam (Islamic Studies) adalah setiap studi yang menyangkut keagamaan, seperti ilmu hadis, fikih, balagah, dan lain sebagainya. Dengan demikian, studi Islam perlu dijadikan sebagai salah satu cabang ilmu yang perlu untuk di perhitungkan . Artinya, ilmu ini sudah mendapatkan perhatian khusus dalam hati para ilmuan, sehingga banyak kampus-kampus yang membuka jurusan studi Islam. Dalam studi tersebut, salah satu persoalan yang mendesak untuk serta dipecahkan adalah masalah 
metodologi. Hal ini disebabkan oleh dua hal. Pertama, kelemahan di kalangan ummat Islam dalam memahami Islam secara komprehensif adalah kurang memahami dalam metodologinya. Kelemahan tersebut mempunyai dampak yang signifikan bagi ummat Islam, khususnya di Negara Indonesia, sebab pemikirannya terkait dengan studi Islam masih mengadopsi pemikir-pemikir barat. Jadi, kelemahan umat silam tidak hanya terhadap penguasaan akan tetapi belum biasa memaknainya secara mendalam dalam. Kedua, ada asumsi dari kalangan ilmuan, bahwa studi Islam akan di masukkan ke dalam ilmu-ilmu yang lain. Misalnya ilmu filologi, dialog agama, antropologi, arkeologi. Karenanya, metode dan pendekatan harus dikuasai dengan benar dan baik sebagai peneliti dalam studi Islam. ${ }^{1}$

Agama' ternyata mempunyai banyak wajah (multifaces) dan bukan lagi seperti orang dahulu memahaminya. Di mana, dahulu agama hanya dipahami sebatas mengatur dalam kehidupan untuk mengenal yang maha kuasa atau cara mendekatkan kepada sang kholik, akan tetapi agama tidak terbatas pada hal-hal yang seperti itu, melainkan persoalan-persoalan historis - kultural yang merupakan keniscayaan manusiawi belaka. ${ }^{2}$ Salah seorang ilmuan Charles J.Adams menawarkan pemikirannya dalam memahami hal-hal seperti itu. (1) bagaimana mendefinisikan Islam dan agama. (2) pendekatan yang relevan dalam proses pengkajian Islam. (3), bidang kajian dalam penelitian dan pengkajian Islam. Dari situlah diharapkan dapat ditemukan pemahaman yang komprehensif mengenai bagaimana semestinya pengkajian agama Islam dijalankan.

Secara etimologi, metodologi berasal dari kata method dan logos. Method artinya cara dan logos artinya ilmu. Secara sederhana metodologi adalah ilmu tentang cara. Metodologi adalah cara yang paling cepat dan tepat dalam melakukan sesuatu. dalam hal ini ilmu tentang cara studi Islam. ${ }^{3}$ metodologi adalah pengkajian dengan penggambaran (deskripsi), penjelasan (explanasi) dan pembenaran (justifikasi). Berdasarkan pendapat Kaflan, metodologi mengandung unsur-unsur ${ }^{4}$ : (1) Pengkajian

\footnotetext{
${ }^{1}$ Amin Abdullah.dkk, Mencari Islam, (Yogyakarta : Tiara Wacana Yogya, 2000), hlm.xi-xii

2 Ahmad Norma Permata, Metodologi Study Agama (Yogyakarta; Pustaka Pelajar, 2000), hal. 1

3 Tafsir (Ed.), 1992, Metoda Mempelajari Islam, Yayasan Nurjati, Cirebon. Hal.9

${ }^{4}$ Abuy Sodikin, 2002, Metodologi Studi Islam. Insan Mandiri, Bandung. Hal.4
} 
(study), (2) Penggambaran (deskripsi), (3) Penjelasan (ekplanasi) dan terakhir Pembenaran (justifikasi).

Studi berasal dari bahasa Inggris, study artinya mempelajari atau mengkaji, yang berarti pengkajian terhadap Islam secara ilmiah, baik Islam sebagai sumber ajaran, pemahaman, maupun pengamalan. Islam berasal dari bahasa Arab, dari kata salima dan aslama. Salima mengandung arti selamat, tunduk dan berserah. Aslama juga mengandung arti kepatuhan, ketundukan, dan berserah. Orang yang tunduk, patuh dan berserah diri kepada ajaran Islam disebut muslim, dan akan selamat dunia akhirat.

Secara istilah, Islam adalah nama sebuah agama samawi yang disampaikan melalui para Rasul Allah, khususnya Rasulullah Muhammad SAW, untuk menjadi pedoman hidup manusia. Di Barat kajian Islam terkenal dengan Islamic Studies, yaitu usaha mendasar dan sistematis untuk mengetahui dan memahami serta membahas secara mendalam seluk beluk yang berhubungan dengan agama Islam, baik ajaranajarannya, sejarahnya, maupun praktek-praktek pelaksanaannya secara nyata dalam kehidupan sehari-hari sepanjang sejarahnya.

Metodologi studi Islam adalah prosedur yang ditempuh secara ilmiah, cepat dan tepat dalam mempelajari Islam secara luas dalam berbagai aspeknya, baik dari segi sumber ajaran, pemahaman terhadap sumber ajaran maupun sejarahnya. Dalam metodologi Studi Islam terdapat prosedur ilmiah, sebagai ciri pokoknya, yang membedakan dengan studi Islam lainnya yang tanpa metodologi.

\section{Metode Pengkajian Islam}

Pembedaan "penelitian agama" dan "penelitian keagamaan" tersebut perlu disadari karena perbedaan tersebut dapat membedakan jenis metode penelitian. Dewasa ini memiliki banyak pandangan apakah ada metode penelitian agama dan penelitian keagamaan. Pihak lain tidak mengakui perbedaannya, dan berpendapat tidak perlu ada. Maka, bila seorang peneliti bermaksud melakukan pengkajian terhadap agama, bisa menggunakan metodologi-metodologi seperti metodologi sosial. untuk mengkaji dan melihat seberapa jauh perbedaan-perbedaan pendapat atau pandangan secara bijak.

Untuk "penelitian agama" yang sasarannya adalah agama sebagai doktrin, pintu pengembangan metodologi penelitian tersendiri sudah terbuka, bahkan sudah 
pernah dirintis. Adanya ilmu usul fikih sebagai metode untuk mengistimbatkan ${ }^{5}$ selain ilmu tersebut ada juga ilmu-ilmu yang lain untuk mengetahui kekuatan atau keautentikan dari pada hadis-hadis nabi sebagai salah satu sumber hukum dalam Islam yaitu. Persoalannya apakah kita hendak menyempurnakannya atau meniadakannya sama sekali, yang berarti menggantikan dengan yang baru, ataukah tidak mengganti sama sekali dan membiarkannya tidak ada.

Untuk "penelitian keagamaan" yang sasarannya adalah agama sebagai gejala sosial, tidak perlu membuat metodologi penelitian sosial yang telah ada. Memang kemungkinan lahirnya suatu ilmu tidak pernah tertutup, tetapi tujuan peniadaannya adalah agar suatu ilmu jangan dibuat secara artifisual karena semangat yang berlebihan. Bila seseorang melakukan sebuah penelitian maka perlu untuk melihat dan memahami metodologi mana yang akan digunakan dalam melakukan penelitian tersebut, maka kejelian dan kehati-hatian seseorang peneliti sangat di butuhkan. ${ }^{6}$

\section{Pendekatan dalam Pengkajian Islam}

Pendekatan merupakan cara pandang atau hasil pemikiran seseorang yang digunakan oleh seorang pengkaji dalam menganalisis serta memahami Islam secara mendalam dengan menggunakan ilmu-ilmu atau teori-teori tertentu. Ilmu-ilmu atau teori tertentu itu pada dasarnya digunakan untuk menganalisis atas permasalahan yang berkaitan dengan agama dengan tujuan untuk mempermudah ruang lingkup kajiannya. Studi dalam agama tersebut dapat berupa dimensi ajarannya maupun dimensi realitasnya. Pendekatan historis digunakan untuk melihat objek kajian dari paradigma Islam sebagai realitas ini, seperti kondisi sosial umat Islam, kondisi politik, peradaban dan kebudayaan. ${ }^{7}$

Charles berpendapat, bahwa, paling tidak ada dua macam penulis agama. Pertama, peneliti yang dilandasi komitmen terhadap agamanya. Kedua, peneliti yang hanya bertujuan untuk memuaskan rasa ingin tahunya. ${ }^{8}$ Dari dua pemetaan tersebut

${ }^{5}$ Istinbat artinya Menetapkan dengan satu metode.

${ }^{6}$ H.m. Atho Mudhar,Pendekatan Studi Islam Dalam Teori dan Praktek, (Yogyakarta: pustaka pelajar,2004), hlm.36-37.

${ }^{7}$ M. Sirozi, dkk.arah baru isalm di indonesia, (Jogjakarta; ar-ruzz media group,2008),hlm.45.

${ }^{8}$ Dr.H.M.Amin Abdullah, Studi Agama; Normativitas atau Historisitas Yogyakarta; Pustaka Pelajar,1996), hal.34 
dapat dijabarkan menjadi beberapa pendekatan secara spesifik sebagaimana tersebut di bawah ini:

\section{Pendekatan Normatif (keagamaan)}

Pengkajian dalam pendekatan ini lebih kepada motivasi atau kepentingan dari pada masing-masing agama tersebut, selain itu prinsip dasar dari pendekatan keagamaan ini bagaimana memahami teks-teks yang tertulis di dalam kitab suci masing-masing agama, dalam pandangan Charles, pendekatan ini dibagi menjadi tiga macam. ${ }^{9}$

\section{Pendekatan Filologi dan Historis}

Pendekatan filologi dalam pengkajian Islam sudah digunakan cukup lama. Pendekatan filologi sangat penting digunakan dalam pengkajian Islam terutama dalam memahami naskah-naskah kuno peninggalan para penulis terdahulu. Begitu pentingnya pendekatan ini maka sangat dibutuhkan dalam pengkajian Islam. Tanpa pendekatan tersebut maka manuskrip-manuskrip atau tulisan-tulisan kuno peninggalan para ulama terdahulu akan sulit untuk dipahami. Selanjutnya naskahnaskah yang sudah diterjemahkan tersebut baik dalam bahasa Jerman, Eropa, Arab dan bahasa-bahasa lain disebarkan ke penjuru dunia guna untuk dimanfaatkan atau digunakan dalam kehidupan sehari hari guna kemajuan peradaban silam. ${ }^{10}$

Pendekatan filologi dalam kajian Islam merupakan suatu yang sangat vital, sebab dengan kajian filologi maka kekayaan Islam baik berupa naskah-naskah atau manuskrip yang ditulis oleh para ulama atau ilmuan muslim terdahulu bias dipahami baik maknanya maupun bias di praktikkan dalam kehidupan sekarang ini. Sehingga seorang ilmuan ternama yaitu Carles mengatakan, studi filologi haruslah diteruskan dalam studi, karena banyak naskah yang meliputi sejarah, teologi hukum, mistik dan lain-lainnya, belum diterjemahkan ke dalam bahasa Eropa dan belum dikaji oleh negara-negara Islam. ${ }^{11}$

Berdasarkan hal tersebut di atas maka pendekatan filologi dalam kajian Islam mempunyai khazanah tersendiri dalam menyebarkan wawasan pemikiran ulama-

\footnotetext{
${ }^{9}$ Ibid hlm.35

${ }^{10}$ Ibid Hlm.45

${ }^{11}$ Ibid hlm.41
} 
ulama terdahulu melalui tulisan-tulisannya berupa manuskrip-manuskrip yang masih terjaga keauntetikannya sampai sekarang. Kemudian hasil dari kajian tersebut disebarluaskan ke Negara-negara Islam di seluruh penjuru dunia dengan tujuan untuk memajukan khazanah Islam dan mengembalikan kejayaan Islam masa lalu yang sudah pudar. Melalui pendekatan seperti ini maka Islam biasa mengembalikan kejayaannya.

\section{PEDEKATAN HISTORIS}

Secara etimologis, sejarah mempunyai banyak arti; Sejarah bisa berarti cerita; suatu rekonstruksi; atau juga kumpulan gejala empiris masa lampau. Secara umum, sejarah mempunyai dua pengertian, yaitu sejarah dalam arti subyektif, dan sejarah dalam arti obyektif. Menurut materinya (subject-matter)nya, sejarah dapat dibedakan atas: (a) Daerah (Asia, Eropa, Amerika, Asia Tenggara, dan sebagainya); (b) Zaman, (misalnya zaman kuno, zaman pertengahan modern); dan (c) Tematis (ada sejarah sosial politik, sejarah kota, agama, seni dll). ${ }^{12}$

Menurut Soerjono Soekanto, pendekatan historis mempergunakan analisa atas peristiwa-peristiwa dalam masa silam untuk merumuskan prinsip-prinsip umum. Metode ini dapat dipakai misalnya, dalam mempelajari masyarakat Islam dalam hal pengamalan, yang disebut dengan "masyarakat Muslim" atau "kebudayaan Muslim". Metode ini sebaiknya dikombinasikan dengan metode comparative (perbandingan). Contohnya ialah seperti yang digunakan oleh Geertz yang membandingkan bagaimana Islam berkembang di Indonesia (Jawa) dan di Maroko. ${ }^{13}$

Perdasarkan di atas, maka pendekatan historis merupakan pendekatan yang digunakan untuk memahami kejadian pada masa lalu secara akurat dan terstruktur, baik mulai dari awal kejadian sampai akhir kejadian tersebut. kegunaan untuk memahami budaya, bahasa, di suatu masyarakat atau Negara tertentu.

Menurut Charles pendekatan historis sangat penting dalam penelitian atau pengkajian Islam, sebab dengan pendekatan ini para peneliti dapat mengetahui

12 Prof. Dr. SUPIANA, M.Ag. Metodologi Studi Islam. Direktorat Jenderal Pendidikan Islam Kementerian Agama 2012. . hal. 90. Tidak dalam terbitan

13 Ibid. hal..90 
perubahan dan perkembangan sebuah peristiwa, hukum, atau bahkan sejarah yang terjadi pada masa lampau secara terperinci dan akurat. ${ }^{14}$

\section{Pendekatan Ilmu Sosial}

Pendekatan sosial merupakan suatu kajian Islam yang berkaitan dengan manusia yang satu dengan manusia yang lain, atau bisa juga antara satu organisasi dengan organisasi yang lain, atau satu partai dengan partai yang lain dengan tujuan suntuk mempererat silaturrahim dan untuk lebih saling kenal mengenal. Objek dari pendekatan ini yaitu masyarakat, yang bersifat empiris teoritis, dan kumulatif. Dan ini juga sesuai dengan teori sosiologi mengatakan "penjelasan apapun dan seperangkat informasi faktual tertentu, atau hubungan informasi dan perkembangannya yang bersifat spesifik harus dikelompokkan pada suatu kerangka kerja yang lebih komprehensif dari tingkah laku manusia". ${ }^{15}$

\section{Pendekatan Fenomenologi}

Menurut Jamali Sahrodi Pendekatan fenomenologi adalah sebuah pendekatan yang didasari oleh filsafat fenomenologi. Yakni mengajarkan pada pentingnya melihat gejala yang tampak dari sebuah entitas untuk menafsirkan alam pemikiran yang berkembang dalam entitas tersebut. Jika fenomenologi digunakan dalam mengkaji Islam berarti seorang peneliti memahami dan menganalisis Islam bukan atas dasar nilai-nilai yang tertuang dalam teks yang bersifat normatif, namun bagaimana seorang peneliti memahami dan menganalisis Islam berdasarkan apa yang dipahami dan diamalkan oleh umatnya. ${ }^{16}$

Menurut Charles, di dalam pendekatan fenomenologi memiliki beberapa ciri tersendiri dengan pendekatan-pendekatan yang lain, di antara ciri-ciri dari pendekatan ini yaitu: Pertama, sebagai usaha memahami agama lain dengan berusaha untuk masuk pada suatu komunitas agama dengan melepaskan atribut yang dimilikinya. Kedua, pendekatan fenomenologi dipandang sebagai suatu pendekatan yang mencoba

\footnotetext{
${ }^{14}$ Charles J.Adams, "Islamic Relegious Tradition" dalam Leonard Binder[edt.], The Study of TheMiddle East; Research and Scholarship ib The Humanities an The Social Sciences (New York; John Wiley dan Sons, 1976), hal. 43

15 Ibid Hlm.45

16. Supiana. Hal.95
} 
mengelompokkan struktur dasar dari fenomena-fenomena agama dengan melintasi batas-batas komunitas agama dan bahasa. ${ }^{17}$

\section{KESIMPULAN}

Setelah menjelaskan kajian agama Islam secara panjang lebar, baik menyangkut pendekatan, wilayah dan perkembangannya, Charles mengakhiri tulisannya dengan sebuah tawaran fokus kajian yang harus diteliti di masa mendatang, diantaranya; Kajian al-Qur'an; menyangkut berbagai persetujuan yang terkandung di dalamnya, yang berisi pengajaran, ide-ide dan pendapat dunia tentang al-Qur'an. Sejarah teologi Islam; fokus pada periode awal dengan memperhatikan pada Mu'tazilah. Kajian sufi; titik beratnya terletak pada persiapan secara detail tentang aktivitas para individu, gerakan, naskah dan ajaran-ajaran mistik. Kajian tentang Syi'ah; difokuskan pada keunikan dan kekayaan kontribusi aliran ini dalam wilayah pengetahuan keagamaan. Kajian tentang agama populer; mengarah pada muslim dan kehidupan pemujaan dalam Islam. Akhirnya yang musti dilakukan adalah memperbaiki metodologi dalam lapangan Islam dan kesadaran untuk mendapatkan melalui munculnya berbagai perbaikan kajian tersebut di Eropa dan Amerika dalam hal ini disiplin kajian keilmuan agama. Tipe seperti ini sering menyebutkan sejarah agama.

\section{DAFTAR PUSTAKA}

Amin Abdullah.dkk, Mencari Islam, (Yogyakarta : Tiara Wacana Yogya, 2000). Ahmad Norma Permata, Metodologi Study Agama (Yogyakarta; Pustaka Pelajar, 2000), Charles J.Adams, "Islamic Relegious Tradition" dalam Leonard Binder[edt.], The Study of TheMiddle East; Research and Scholarship ib The Humanities an The Social Sciences (New York; John Wiley dan Sons, 1976), hal. 43 Lihat Haidar Bagir,"Fenomena Schimmel" Pengantar dalam Annemarie Schimmel, Rahasia Wajah Suci Ilahi,terj. Rahmani Astuti[Bandung; Mizan,1996]

Dr.H.M.Amin Abdullah, Studi Agama; Normativitas atan Historisitas(Yogyakarta; Pustaka Pelajar,1996)

H.M. Atho Mudhar,Pendekatan Studi Islam Dalam Teori dan Praktek, (Yogyakarta: pustaka pelajar,2004)

M. Sirozi, dkk.arah baru isalm di indonesia, (Jogjakarta; ar-ruzz media group,2008)

${ }^{17}$ Charles J.Adams, Ibid, hal. 49-50 
Suparlan

Nabilah Lubis, Naskah dan Metode Penelitian Filologi (Jakarta; Forum Kajian Bahasa dan Sastra Arab, 1996)

Diakses dari http://yunanhidayatstaimus.blogspot.com/2011/04/pendekatan-dalampengkajian-Islam. pada 25 November 2013 